\title{
Variações materiais, manutenções de forma e conteúdo: distopias infantojuvenis
}

\author{
Carlos Gontijo Rosa a (D) \\ Beth Brait b ${ }^{b}$
}

\begin{abstract}
RESUMO
Este estudo visa legitimar as distopias enquanto um gênero discursivo que coloca criadores $e$ auditório em diálogo profundo sobre as condições sociais em que vivem. Ele parte das distopias como gênero literário com projeção na produção artística contemporânea direcionada ao público infantojuvenil, conectando objetos estéticos produzidos em diferentes materialidades, como cinema, romance e quadrinhos. Para melhor comparar objetos distintos entre si, coletamos como corpus distopias infantojuvenis de temática ambiental. A distopia, então, é uma narrativa contada com determinada estrutura $e$ organização dos acontecimentos: há de início a descrição de um futuro catastrófico, mas possível; no seu decorrer, surgem indícios de como as coisas pas-
\end{abstract}

a Pontifícia Universidade Católica de São Paulo, Programa de Estudos Pós-Graduados em Linguística Aplicada e Estudos da Linguagem, São Paulo, SP, Brasil. E-mail: carlosgontijo@gmail.com

b Pontifícia Universidade Católica de São Paulo, Programa de Estudos Pós-Graduados em Linguística Aplicada e Estudos da Linguagem, Programa de Estudos Pós-Graduados em Literatura e Crítica Literária, São Paulo, SP, Brasil. E-mail: bbrait@uol.com.br

\section{Como citar:}

GONTIJO ROSA, C.; BRAIT, B. Variações materiais, manutenções de forma e conteúdo: distopias infantojuvenis. Gragoatá, Niterói, v.26, n.54, p. 521-557, 2021. <https://doi.org/10.22409/gragoata.v26i55.9999> 
saram do presente do leitor ao futuro proposto pela distopia, com culpabilização da humanidade; um final apaziguador; e, permeando tudo, um herói cuja identificação com o leitor é imediata. A estabilidade formal percebida nesses enunciados nos levou à teoria bakhtiniana, especialmente ao tex to O problema do conteúdo, do material e da forma na criação artística (1924). Por não perceber o objeto estético fechado em sua materialidade, Bakhtin valoriza o conteúdo como indispensável, o qual se manifesta através de uma forma que se imprime sobre uma materialidade. Como a forma distópica descrita acima enuncia um conteúdo que se relaciona de maneira única com o exterior do enunciado, também discutimos o problema da materialidade e porque ela toma frente nas análises críticas de objetos artísticos ainda hoje. Concluímos que a distopia, como gênero discursivo, faz com que o objeto estético reverbere nos âmbitos éticos e cognitivos da sua realidade.

Palavras-chave: Distopia. Gêneros literários. Gêneros discursivos. Literatura Infantojuvenil.

Distopias são espelhos negros, versões corrompidas de futuros que batem na nossa porta.

Bruno Vaiano, Revista Galileu, 28/11/2016

\section{Introdução}

A epígrafe deste artigo nos mobiliza a dois pensamentos distintos acerca das obras distópicas que circulam na esfera artística do discurso. O primeiro deles se refere à condição de enunciado presente que se projeta para o futuro. Nesse aspecto, evocamos o que escreve Berriel:

a distopia busca colocar-se em continuidade com o processo histórico, ampliando e formalizando as tendências negativas operantes no presente que, se não forem obstruídas, podem conduzir, quase fatalmente, às sociedades perversas (a própria distopia). (BERRIEL, 2005, p. 6-7, grifo do autor)

A distopia está calcada no momento presente da sua escrita, a partir do qual o autor antecipa um futuro possível. Para Claeys: 
${ }^{1}$ The term [dystopia] is used here in the broad sense of portraying feasible negative visions of social and political development, cast principally in fictional form. By 'feasible' we imply that no extraordinary or utterly unrealistic features dominate the narrative. Much of the domain of science fiction is thus excluded from this definition:

Wells's The War of the Worlds (1898), for instance, is not based on the extrapolation of some existing trend as such, and is thus not a dystopia. (CLAEYS, 2010, p. 109). Todas as traduções apresentadas neste artigo foram

feitas pelo autor, exceto quando indicada outra autoria da tradução.

Não sendo a literatura um objeto estático, as restrições propostas para a leitura das "origens da distopia", título do capítulo de

Claeys, não se aplicam completamente à distopia escrita no fim do século XX e século XXI, proposta como corpus deste artigo.

\begin{abstract}
2 The novel [Wells's The Time Machine] is not about the impact of technology, although it certainly could be called a dystopia - it is a vision of the future in which class division and conflict have led to a degraded society. (FITTING, 2010, p. 139).
\end{abstract}

\footnotetext{
${ }^{3}$ Marcamos o adjetivo "distinto" por entendermos, apoiados em Fitting (2010), bem como em outros autores do The Cambridge Companion to Utopian Literature (2010), que a distopia não é um subgênero da ficção científica, mas apresenta características únicas que a distinguem enquanto gênero literário e, como se verá, discursivo.
}

\begin{abstract}
O termo [distopia] é usado aqui no sentido amplo de retratar uma visão negativa factível do desenvolvimento social e político, inserido principalmente na forma ficcional. Por 'factível' dizemos que nenhuma característica extraordinária ou totalmente irreal domina a narrativa. Muito do campo da ficção científica é, assim, excluído da definição: A guerra dos mundos (1898), de Wells, por exemplo, não se baseia na extrapolação de algumas tendências existentes em si, não sendo, assim, uma distopia. ${ }^{1}$ (CLAEYS, 2010, p. 109, tradução nossa).
\end{abstract}

Em outro caminho de pensamento, Fitting tem uma visão um pouco mais ampla, identificando Wells entre os autores distópicos:
A novela [A máquina do tempo, de Wells] não fala sobre o impacto da tecnologia, apesar de certamente poder ser chamada de distopia - é uma visão do futuro em que a divisão de classes e os conflitos conduziram a uma sociedade degradada². (FITTING, 2010, p. 139, tradução nossa)

Embora ambos concordem que A máquina do tempo de Wells seja uma narrativa de ficção científica com conotações distópicas, sua análise, empreendida por Fitting, coloca em diálogo dois gêneros literários distintos ${ }^{3}$ : a ficção científica e a distopia. Ao fazer isso e estender o corpus de seu texto para finais do século XX, Fitting aceita novas formas da escrita distópica, lendo o gênero de maneira produtiva, e não estática.

A qualidade "negativa" da distopia em sua relação com a realidade, convocada por Berriel e Claeys, introduz nosso segundo pensamento extraído da epígrafe: a ideia de que os enunciados distópicos são "versões corrompidas" da realidade. Tal visão também coaduna com a de Fitting (2010, p. 141, tradução nossa) ao afirmar que "a crítica da sociedade contemporânea expressa na distopia implica (ou garante) a necessidade de mudança" ${ }^{\prime \prime}$, como uma convocação de sua audiência para a mudança - o que coloca em primeiro plano a recepção das obras.

Temos, portanto, a possibilidade de identificar nos textos distópicos seu contexto de produção e seu auditório - o público (leitor, espectador, ouvinte) para o qual era inicialmente dirigido.

Neste ponto, Volóchinov já alerta para outros aspectos extraverbais do discurso: 
4 the critique of contemporary society expressed in the dystopia implies (or asserts) the need for change. (FITTING, 2010, p. 141)

${ }^{5}$ Os três aspectos subentendidos da parte extraverbal do enunciado, encontrados por nós - o espaço e o tempo do acontecimento do enunciado (o "onde" e o "quando"), o objeto ou tema do enunciado ("sobre o quê" se fala) e a relação dos falantes com o ocorrido ("avaliação") -, convencionamos chamar por uma palavra já conhecida: situação (VOLÓCHINOV, 2019, p. 285).

\footnotetext{
${ }^{6}$ Embora não haja um consenso sobre os limites desta classificação, ela costuma ser descrita como a faixa etária entre os 12 e os 20 ou 24 anos. De certa forma, o termo relaciona-se com o que a Organização Mundial da Saúde estabelece como adolescência (dos 10 aos 20 anos) e juventude (dos 15 aos 24 anos). Entretanto, de acordo com Schoen-Ferreira, Aznar-Farias e

Silvares, a questão é muito mais voltada a um momento da vida do que a números especificamente: "A sociedade contemporânea ocidental não apenas estendeu o período da adolescência, como também os elementos constitutivos da experiência juvenil e seus conteúdos (Abramo \& Branco, 2005). Adolescência, hoje, não é mais encarada apenas como uma preparação para a vida adulta, mas passou a adquirir sentido em si mesma" (SCHOEN-FERREIRA, AZNAR-FARIAS, SILVARES, 2010, p. 228).
}

Além da parte verbal expressa, todo enunciado cotidiano (como ficará evidente um pouco adiante) consiste de uma parte não expressa, porém subentendida e extraverbal (situação ${ }^{5}$ e auditório), sem a qual não é possível compreender o próprio enunciado. (VOLÓCHINOV, 2019, p. 269, grifos do autor).

Assim, por entender que as questões de situação e auditório são essenciais para compreender os discursos artísticos distópicos, delimitaremos nosso objeto de estudo aos seguintes textos produzidos no século XXI, direcionados ao público infantil, juvenil e jovem adulto ${ }^{6}$ : o mangá Nausicaä do Vale do Vento, publicação em sete volumes de Hayao Miyazaki em 1983, animado em 1984 pelo Studio Ghibli; a animação Wall-E, produzida pela Pixar Animation Studios em 2008; a trilogia romanesca Jogos vorazes (2008-2010), transformada em uma tetralogia cinematográfica pela Lions Gate Entertainment (2012-2015); o romance A vida no céu: romance para jovens e outros sonhadores, do autor angolano José Eduardo Agualusa, publicado em 2013; e a série original Netflix Perdidos no espaço (2018-2021), regravação da série homônima de 1965, produzida pela Legendary Television.

O que objetos materialmente tão diferentes possuem em comum é o fato de caberem na descrição forjada por Berriel para o gênero literário distopia. Quanto ao que defende Claeys e demais autores do The Cambridge Companion to Utopian literature (2010) - que "imagens de um futuro são formuladas como possibilidades reais" ${ }^{\prime 8}$ (VIEIRA, 2010, p. 17, tradução nossa), ou ainda retomando o adjetivo "feasible" (factível) levantado por Claeys -, pensamos que hoje em dia não é inverossímil supor um robô como o de Perdidos no espaço, uma viagem pelo espaço como em Wall-E ou um sistema de vida flutuante como o de A vida no céu. Além disso, todos os objetos deste artigo apresentam uma relação com o gênero ficção científica9 ${ }^{9}$ o que limita ainda mais nosso leitor presumido.

\section{A construção da narrativa: uma estrutura geral}

Primeiramente, interessa dizer que, por mais que apresentem diferenças, todos os objetos artísticos acima listados compartilham o fato de conterem e serem calcados em uma narrativa. Reivindicada na teoria literária pelo gênero épico ou narrativo, tomamos o conceito por uma perspectiva 
7 Informação veiculada no site oficial de notícias do streaming. Disponível em: http:// media.netflix.com. Acesso em: 06 fev 2021.

${ }^{8}$ images of the future are put foward as real possibilities. (VIEIRA, 2010, p. 17)

9 Tal associação, entretanto, não pode ser tomada como característica

fixa de nenhum dos dois gêneros, como afirma Fitting (2010, p. 149, tradução nossa): “Tenho tentado mostrar que não há uma conexão obrigatória entre utopia e ficção científica, e que, nos últimos anos, elas têm se afastado" (I have been trying to show that there is not a necessary connection between utopia and science fiction, and in recent years the two have drifted apart).

${ }^{10}$ Eudoro de Sousa traduz o termo aristotélico mythos como intriga em sua tradução da Poética.

Além disso, associa os termos por várias vezes escrevendo "mito (intriga)", bem como descreve o conceito de "intriga" das seguintes formas: "composição, estrutura do mito, trama dos fatos" (SOUSA, 2003, p. 281);

"composição dos atos" (p. 283). O estudioso ainda relaciona o termo "intriga" a outros elementos constituintes da narrativa: "É então que introduz o 'reconhecimento' e a 'peripécia', o 'nó' e o 'desenlace' da intriga, que devem resultar da trama dos fatos" (p. 37); ou "mito = intriga = composição dos atos = imitação poética" (p. 170). mais ampla, como sinônimo de enredo ${ }^{10}$, para a qual a narrativa é a estrutura e organização dos acontecimentos. Assim, por exemplo, Alves atribui à principal figura do gênero literário épico nova roupagem, de acordo com as obras artísticas modernas e contemporâneas:

o narrador é um instrumento que não tem de se revelar apenas através da linguagem verbal articulada, nem, tampouco, terá de estar representado por uma personagem audível, a própria câmara associada a técnicas cinematográficas de som e luz cede à cena o papel de narrador (ALVES, 2009, n. p.).

Para tal perspectiva quanto à narrativa, convocamos o pensamento de Bakhtin (2019, p. 109), para quem "na presença do romance, todos os gêneros começam a soar de modo diferente", no sentido de um contato da obra de arte com uma "realidade inacabada", da qual o leitor participa ativamente:

em vez da nossa vida enfadonha, [os romances de aventuras, por exemplo,] nos oferecem, é verdade, um sucedâneo, mas trata-se de uma vida interessante e brilhante. É possível covivenciar essas aventuras, autoidentificar-se com essas personagens; tais romances quase podem tornar-se substitutos da nossa própria vida. Nada de semelhante é possível em relação à epopeia e outros gêneros distanciados. (BAKHTIN, 2019, p. 101, grifo do autor).

A identificação do leitor com o herói do romance, já em seus primórdios, também diz respeito ao momento histórico em que a ascensão do gênero ocorre: no final do século XVIII e no século XIX, início da Idade Moderna, a burguesia se torna predominante no cenário social. Assim,

o romance tornou-se o personagem central do drama do desenvolvimento literário na Idade Moderna precisamente porque é quem melhor expressa as tendências da formação de um novo mundo, pois é o único gênero concebido por esse mundo e em tudo consanguíneo a ele. (BAKHTIN, 2019, p. 70 , grifo do autor).

Embora o autor russo relacione o encontro entre romance e realidade ao "inacabamento" de ambos, a perspectiva sociológica também opera no campo epistemológico da teoria bakhtiniana. Não é insignificante, portanto, o fato de que toda uma primeira geração de narrativas distópicas tenha sido 
veiculada por meio de romances: 1984, de George Orwell, Admirável mundo novo, de Aldous Huxley, e, claro, Guerra dos mundos, de H. G. Wells. (Cf. CLAEYS, 2010). Entretanto, com o passar do tempo, a narrativa distópica escoa para outras formas do discurso artístico.

Nesta seção, portanto, o enfoque é direcionado à narrativa e à sua elaboração. Iniciaremos por descrever sumariamente as narrativas das obras levantadas como corpus deste trabalho, enfatizando pontos caros à nossa análise, que apresentam relativa estabilidade na estrutura que compõe narrativas tão variadas.

No mangá Nausicaä do Vale do Vento, Miyazaki já na primeira sequência narrativa apresenta um mundo diferente do nosso, em que uma floresta envenenada ameaça a vida humana do planeta. Também já desde o início nos é apresentada a protagonista que dá título à série e que já em sua primeira ação demonstra "compreender" o ambiente selvagem. No decorrer da narrativa, uma guerra desenrola-se entre as potências desse novo mundo, na qual o Vale do Vento precisa tomar parte. Durante a guerra, são fornecidas ao leitor informações sobre o passado do mundo de Nausicaä e como ele chegou a ser como é: houve uma guerra anterior que quase devastou o mundo, causada pela ambição dos homens. No final, o elo de Nausicaä com a natureza restabelece um equilíbrio que seja benéfico para a sobrevivência da humanidade e para a regeneração do planeta.

Wall-E (sigla de Waste Allocation Load Lifiters - EarthClass, em inglês) é um robô de alocação de resíduos que fica encarregado de limpar a Terra, enquanto a população humana se recolhe no espaço. Quando saíram do planeta, 700 anos antes do momento presente da narrativa, os humanos deixaram muitos robôs, que foram parando de funcionar, até restar apenas o protagonista do filme. A intriga começa quando a robô EVA (do inglês EVE: Extra-Terrestrial Vegetation Evaluator, Avaliador de Vegetação Extraterrestre, em tradução livre) chega à Terra para buscar uma planta, que seria o sinal de que o planeta voltara a ser habitável. Pois ela descobre a planta e entra em modo de hibernação, momento da narrativa em que Wall-E cuida dela e se apaixona - o robô-lixeiro acaba seguindo-a até a espaçonave Axiom, que navega pelo Universo com os humanos remanescentes. Lá, primeiramente descobrimos como o espaço 
afetou a composição física da humanidade, uma denúncia da preguiça e acomodação humanas. Ainda se descobre que a Terra foi declarada inabitável por causa da quantidade de lixo produzida pelos humanos e o robô-navegador Auto (do inglês Autopilot, ou piloto automático), que sempre segue suas diretrizes de programação, deve manter a fachada inicial. Ao final, EVA, Wall-E e outras personagens robôs e humanas que os ajudam conseguem iniciar o protocolo de volta à Terra. Nos créditos, é mostrado em desenhos estáticos, num misto de pinturas rupestres ou desenhos infantis, a recolonização da Terra pela humanidade.

A narrativa de Jogos vorazes se passa no país-continente Panem. Nela, a jovem Katniss Everdeen é levada a disputar os jogos mencionados no título, que correspondem a uma matança entre representantes dos 12 distritos de Panem, à moda do pão e circo romanos, que denotam igualmente a crueldade humana com seus semelhantes e a desigualdade de classes no país. Nos raros momentos em que se fala de uma vida e uma realidade anterior àquela, sabe-se vagamente de $o$ cataclisma ambiental ocorrido para a constituição desta nova configuração social. Ao final da trilogia/tetralogia, em meio a vários plot twists, o governo autoritário é deposto com intensa participação da protagonista, que entretanto se vê ostracizada do convívio na Capital.

A vida no céu: romance para jovens e outros sonhadores conta a história de um mundo em que o aquecimento global derreteu as calotas polares e os homens tiveram de encontrar formas alternativas de vida, pois não havia mais terra seca na superfície terrestre. O mar mostra-se inabitável pela temperatura próxima à água e os homens precisam morar em balões (cujo coletivo compõe "aldeias") e dirigíveis, no céu. O narrador-protagonista Carlos Tucano, angolano, mora na aldeia Luanda e procura seu pai, desaparecido numa tempestade. Na sua busca, além do pai, encontra Aimée, sua futura namorada na trama, e Sibongile, uma sangoma (feiticeira) que vai lhe propor sua segunda busca: a Ilha Verde. Entretanto, Carlos conhece também Boniface e sua quadrilha de piratas, os quais tentam sabotar a vida que se reorganiza no céu e a busca de Carlos e seu grupo pela terra firme. Por fim, o grupo de Carlos encontra a Ilha Verde, que é habitada, e o protagonista acaba se tornando o embaixador da Ilha Verde entre os povos do céu. 
A narrativa de Perdidos no espaço começa in media res, no meio de um acidente espacial que faz a nave da família Robinson pousar num planeta desconhecido. Eles fazem parte de um grupo de humanos aos quais é possibilitado viver fora da Terra, no planeta Alpha-Centauri. Para tanto, todos os que embarcam devem passar por rigorosos testes físicos e mentais e especializar-se em alguma atividade que seja "útil" à comunidade formada no espaço. $\mathrm{O}$ recurso mais utilizado para a referência ao passado são os flashbacks. Durante toda a primeira temporada, o seriado se detém num futuro mais próximo, explicando o que causara o acidente da primeira cena. Entretanto, já se sabe que a Terra se tornou inabitável. Na segunda temporada, sabemos que o cataclisma foi provocado por um meteoro, que pode, entretanto, ter também sido a chegada de uma nave alienígena no planeta, pois já se sabe que a Resolute, nave-mãe que leva os humanos selecionados a Alpha-Centauri, funciona com tecnologia extraterrestre. As tentativas dos alienígenas (figuras similares a robôs) para recuperar sua tecnologia e a ambição humana são os motores centrais do grande conflito que contorna as relações estabelecidas entre os Robinsons e entre estes e os demais participantes da narrativa.

Como se pode perceber, a fim de melhor organizar nosso pensamento acerca das distopias e mostrar a proximidade narrativa entre tantas materialidades discursivas diferentes, seguimos o ramo da distopia ambiental. $\mathrm{O}$ adjetivo delimita o assunto dos discursos, de maneira que os paralelismos e aproximações fiquem mais claros, pois todos eles, em certa medida, vão falar da relação do homem com a natureza.

Os resumos apresentados de nossos objetos de estudo, objetos levantados para este artigo é Wall-E. Contudo, a personalidade adolescente do robô transparece na sua relação com o amor que sente por EVA. Já a família Robinson, de Perdidos no espaço, representa, de certa forma, um herói coletivo; entretanto, os filhos Judy (18 anos), Penny (15 anos) e Will (11 anos) podem servir para fins de identificação do espectador adolescente ou jovem adulto. embora sumários, deixam entrever algumas estruturas fixas de suas formas narrativas. Contamos sempre com uma apresentação inicial da realidade distópica em seu momento atual, deixando razoavelmente claro que se trata de um mundo futuro ao nosso, mas pior - característica essencial de um discurso distópico. Além disso, existe uma personagem central com a qual o auditório se identifica; em se tratando de narrativas infantojuvenis, existe a tendência a uma correlação mais direta - uma personagem adolescente que enfrenta as dificuldades do mundo ao redor ao mesmo tempo em que lida com questões tipicamente adolescentes ${ }^{11}$. No decorrer da 
${ }^{12}$ Diz-se que o livro de H. G. Wells inaugura o gênero. Entretanto, obras anteriores, como Frankenstein (1823) e $O$ último homem (1826), de Mary Shelley, dentre outras, já antecipam mundos distópicos, embora se relacionem melhor com o gênero fantástico. Por outro lado, autores como Alexandra Aldridge consideram a "distopia paradigmática" o romance Nós, escrito por Eugene Zamiatin entre 1920 e 1921 e publicado em 1924

13 Para Berriel (2005, p. 5), "é bem sabido que a distopia nasceu da utopia, e que ambas expressões são estreitamente ligadas. Há em toda utopia um elemento distópico, expresso ou tácito, e vice-versa."

\section{4 "É ofício de poeta} narrar o que aconteceu; é, sim, o de representar o que poderia acontecer, quer dizer: o que é possível segundo a verossimilhança e a necessidade. Com efeito, não diferem o historiador e o poeta, por escreverem verso ou prosa (pois que bem poderiam ser postas em verso as obras de Heródoto, e nem por isso deixariam de ser história, se fossem em verso o que eram em prosa) diferem, sim, em que diz um as coisas que sucederam, e outro as que poderiam suceder. Por isso a poesia é algo de mais filosófico e mais sério do que a história, pois refere aquela principalmente o universal, e esta, o particular" (ARISTÓTELES, IX, 50, 2003, p. 115)

15 A reportagem refere-se ao Relatório Planeta Vivo 2006, cuja conclusão sintetiza na sentença: "se as narrativa, quando já houve a conexão entre personagens e auditório, há a revelação mais ou menos explícita dos motivos que desencadearam a catástrofe que moldou o mundo daquela forma - invariavelmente, eles têm relação com uma ação humana mais contundente para efetivação da catástrofe. $\mathrm{O}$ final, entretanto, tende a amenizar um pessimismo inerente à narrativa pela revolta relativamente bem sucedida do herói. Esses elementos serão detalhados a seguir.

\section{A construção do gênero em diferentes materialidades da esfera artística}

\section{De início, o pior futuro}

A distopia nasce de um novo olhar sobre o mundo que se aproxima temporal e criticamente do movimento literário realista. No século XIX, após o deslumbramento romântico com a nova classe social dominante - a burguesia -, há o apontamento de suas mazelas nos âmbitos social, religioso, político e cultural pelos artistas realistas. Concomitantemente, é publicada $A$ máquina do tempo, de H. G. Wells (1895) ${ }^{12}$. Há, portanto, na construção do universo ficcional distópico, a presença da humanidade, sua índole e suas vontades como matriz de conflito. Em consequência, ao evocar a ideia de humanidade - e, à vista disso, de sociedade - na literatura, não escapamos a uma confrontação com a realidade. Para tanto, diz Berriel que

as utopias ${ }^{13}$, partindo de elementos reais, reconstroem todas as Histórias possíveis, todos os cenários que a História não realizou. A raiz desta ideia vem da Poética de Aristóteles, onde está dito ser a poesia mais ampla que a História, pois realiza até o fim aquilo que a História apenas esboçou. ${ }^{14}$ (BERRIEL, 2005, p. 6).

A distopia, portanto, estaria sempre submetida às noções de verossimilhança, pois ligada aos fatos e à realidade históricos coetâneos à sua escrita e publicação. Veja-se, por exemplo, a relação estabelecida entre o filme Wall-E, de 2008, e as informações contidas na reportagem da WWF de 2006, intitulada "Relatório ${ }^{15}$ afirma que consumo humano supera capacidade de recuperação do planeta". Por outro lado, justamente por não ser um discurso comprometido com 
atuais projeções se concretizarem, a humanidade

consumirá perigosamente até 2050 duas vezes mais recursos que o planeta pode gerar por ano". Disponível em: https://www. wwf.org.br/index. cfm?uNewsID=4400. Acesso em: 20 ago. 2020.

\section{Entendemos \\ "cronotopo" no mesmo sentido que Bakhtin (2018b, p. 11), em Teoria do romance II: "a interligação essencial das relações de espaço e tempo como foram artisticamente assimiladas na literatura".}

17 Para Alonso (2009, n. p.), a verossimilhança interna "emerge da própria estrutura da obra apresentando os componentes fundamentais de sua coesão interna, congruentes com as demais partes da construção narrativa que dessa forma não parece imposta ou enxertada como um corpo estranho dentro da obra narrativa. Esta forma de verossimilhança está diretamente relacionada ao modo mesmo como a obra está sendo concebida como objeto de representação linguística e simbólica e assim confunde-se com a própria mímese tanto em seu sentido de produto como de produção".

18 Tomamos, para padrão de comparação, a definição de utopia presente em Berriel (2005, p. 6, negrito do autor): "a utopia clássica se desenvolve construindo um hiato (insanável) entre a História real e o espaço reservado para as projeções utópicas; uma verdade histórica, a distopia escapa a um compromisso historiográfico e propõe um deslocamento do espaço-tempo "real":

A verossimilhança, portanto, sempre resulta de um cálculo sobre a possibilidade de real contida pelo texto e sua afirmação depende menos da obra que do juízo exercido pelo destinatário. A obra por si não se descobre verossímil ou não. Este caráter lhe é concedido de acordo com o grau de redundância que contém. (LIMA, 1973, p. 56).

Neste sentido, a distopia constrói uma possibilidade do real num espaço fora do tempo real, um outro cronotopo ${ }^{16}$, ficcional, em que a verossimilhança interna ${ }^{17}$ da obra supõe uma nova leitura da realidade circundante do/pelo leitor:

exigimos do autor verossimilhança axiológica, ponderabilidade de valor-acontecimento das suas imagens, uma realidade de acontecimento (um movimento possível não em termos físicos mas em termos de acontecimento). (BAKHTIN, 2018a, p. 184).

A percepção da humanidade nos universos criados nas utopias ${ }^{18}$ e distopias, especialmente aquelas escritas na era moderna, tende a ser equivalente, embora em sentidos diferentes. Enquanto a utopia busca o equilíbrio da forma citadina apesar das características essencialmente negativas do humano - imprevisibilidade, perversidade, ganância -, a distopia reforça alguns desses aspectos de forma que a projeção futura das ações humanas leve a uma realidade pior do que a coetânea. Ou seja, em ambas as visões de mundo, o ser humano carrega caráter negativo, que é anulado na "cidade perfeita" e enfatizado num futuro distópico:

A distopia sempre foi uma forma de conceber a realidade e os medos humanos. [...] "a distopia repensa sim medos da contemporaneidade que circunda o autor empírico". Na sua visão, esse é o movimento da arte, "mas as distopias potencializam isso [os medos] por meio de uma estética específica. Foi algo que emergiu na história da literatura, assim como outras estéticas emergiram e compuseram uma historicidade". (GEISLER, 2019, p. 42).

As aspas na citação anterior, oriundas de uma entrevista da autora com a pesquisadora Caroline Becker, apresentam 
a descoberta de um país distante, até então ignorado (como no enredo de Morus, Campanella e outros) se tornou símbolo de uma fratura não apenas geográfica, mas, sobretudo histórica".

${ }^{19} \mathrm{O}$ pessimismo com o início do século XX, marcado pelas duas guerras mundiais, crack da Bolsa de Nova York e demais eventos catastróficos nos âmbitos políticos, sociais e econômicos pesaram de forma aguda não apenas nos autores distópicos, mas em todo o imaginário artísticoliterário do período. Veja-se, por exemplo, a dramaturgia de Bernard Shaw ou a poesia da segunda fase de Carlos Drummond de Andrade (Sentimento do mundo, 1940), em cuja coletânea se encontra o emblemático

"Congresso

Internacional do

Medo".

20 "Em cada época da evolução da linguagem literária, o tom é dado por determinados gêneros do discurso." (BAKHTIN, 2016, p. 20)

${ }^{21}$ A influência do pensamento darwiniano se faz marcante na literatura distópica. justamente o funcionamento, a origem deste aspecto "negativo" nas distopias. Por outro lado, o deslocamento espaço-temporal na utopia gera a não efetividade desse mundo, que não pode coexistir com a realidade; a projeção do futuro na distopia denuncia os efeitos efetivos extremos da ação humana no mundo. Assim, se

a escolha dos meios linguísticos e dos gêneros de discurso é determinada, primeiramente, pelas tarefas (pela ideia) do sujeito do discurso (ou autor) centradas no objeto e no sentido. É o primeiro elemento do enunciado que determina as suas peculiaridades estilístico-composicionais. (BAKHTIN, 2016, p. 47).

faz sentido, portanto, a escolha da distopia como caminho de o autor expor seu pensamento sobre o mundo, especialmente se nos localizarmos no século $X X$, no período coetâneo e posterior à Primeira Guerra Mundial ${ }^{19}$ :

Foi durante o século 20 que a literatura distópica se consolidou, tomou corpo, ganhou notoriedade e se firmou como uma das marcas desse tempo. Houve condições para isso, para a emersão de uma forma de pensar, imaginar e escrever sobre o futuro como um tempo no qual as coisas se tornariam piores. Até o século 19, o sentimento em relação aos dias que viriam não costumava ser tão povoado por imagens de um pesadelo. Um pensador ou um escritor, quando pensava sobre o futuro, facilmente imaginava que o ser humano seria capaz de conduzir seus passos para mundos melhores. Projetava a vida a partir de desígnios normalmente otimistas e depositava fé na ciência, na tecnologia, na racionalidade e, sobretudo, na benevolência do ser humano como as condições capazes de arquitetarem a vida ideal no futuro. Imaginava-se um sonho ou algo parecido com um paraíso na Terra para os dias que viriam. (KOPP, 2011, p. 10).

O autor contemporâneo, portanto, encontra na distopia a forma discursiva adequada à vazão de seus medos, não mais projetados num ideal otimista de sociedade. ${ }^{20} \mathrm{O}$ gênero que começou na utopia se transforma, mas ainda parte do mesmo pressuposto de construção de sua narrativa: a adaptabilidade do humano ao ambiente que se lhe apresenta - processo evolutivo $^{21}$ que não quer dizer, necessariamente, melhoria ou aperfeiçoamento. 
${ }^{22}$ Isso, quando falamos da distopia em sua vertente ambiental. Quando se trata de uma distopia social, é a interferência do homem na sociedade; quando distopia tecnológica, a relação entre homem e tecnologia, e assim sucessivamente.

${ }^{23}$ Veja-se, para tanto, a reportagem "Seis referências históricas em 'Jogos vorazes'”, da Turma do Fundão, blog da revista Superinteressante. Disponível em: https:// super.abril.com. br/blog/turma-dofundao/6-referenciashistoricas-em-jogosvorazes/. Acessado em: 20 ago. 2020.

${ }^{24}$ A partir d'aquest
principi, la
representació ha
creat infinitat de
convencions basades
en la complicitat més
o menys manifesta del
locutor de la ficció amb
l'interlocutor present
extraficcional. [...] Aixi,
el text pot situar els
personatges actuant
i expressant-se dins
del pla estrictament
ficcional, mantenint
l'espectador com a
receptor privilegiat
del que podriem
anomenar l'espectacle
de la comunicació.
La comunicació
es converteix en
espectacle i s'ofereix a
un espectador passiu,
en aquest cas. Però això
no deixa de ser relatiu,

Ação humana e agravamento da crise

A presença da humanidade como elemento fulcral para o desenvolvimento ou agravamento da crise que se instaura no mundo distópico representado é outra similaridade entre os objetos aventados para este estudo. Se, no início da narrativa, somos apresentados às condições presentes do tempo-espaço da narrativa; no seu decorrer, as condições que levaram à situação atual são compartilhadas com o auditório. E elas sempre têm relação com a presença e a interferência incisiva dos seres humanos no ambiente ${ }^{22}$.

As narrativas distópicas, nas diversas materialidades, costumam ser lineares em seu aspecto geral. Entretanto, no seu decurso, surgem algumas referências ao passado, que servem de elo entre a nossa realidade e a realidade retratada ou como explicação para a situação atual da narrativa. No caso dos objetos analisados, a explicação dos eventos causadores do cataclisma são uma transmissão antiga gravada (Wall-E), a explicação através da voz do narrador ( $A$ vida no céu) ou de personagens (Nausicaä do Vale do Vento) ou o clássico recurso do flashback (Perdidos no espaço). Em Jogos vorazes, um passado anterior à constituição do país-continente Panem é apenas superficialmente mencionado - prevalecendo a referência a um passado mais próximo: a disputa entre a Capital e o Distrito 13. Embora essa disputa possa ser relacionada com conflitos existentes na nossa realidade $\mathrm{e}^{23}$, o apagamento da história da construção daquela sociedade pode ser lido como a metáfora da opressão da própria população, que não tem domínio sequer da sua história e da sua memória.

Seja qual for a forma principal pela qual o autor decida revelar essa parte da narrativa, todas carregam características em comum: no conteúdo, a ação humana é desencadeadora e principal catalisadora da crise; na forma, essas informações são transmitidas "a conta-gotas", utilizando-se o recurso do doseamento de informação.

Termo emprestado dos estudos teatrais, o "doseamento de informação" trata de como e quando as informações dos acontecimentos que ocorreram fora de cena (em outro espaço ou tempo) são apresentados ao espectador (e, eventualmente, também às personagens): 
perquè, encarna que no s'involucri directamente el receptor que es troba fora de la ficció en la situació de comunicació, les estratègies dramàtiques que utiliza un autor en ocasions poden dosificar la informació, de manera que el receptor exterior sàpiga més que el receptor de la ficció o al revés, que el receptor intern a la ficció sàpiga més coses que el receptor extern. (ABELLAN, 2000, p. 37-38, grifo nosso).

${ }^{25}$ Como fala o Fandom de Jogos vorazes: "Em um futuro indeterminado, o rosto da mudança da terra e da civilização moderna foi aparentemente destruída. Não se sabe exatamente o que causou o 'fim do mundo'. As massas de terra mudaram de forma. A atmosfera foi completamente destruída e o nível do mar subiu drasticamente. Algum tempo depois do possível 'fim do mundo', uma nação foi estabelecida na América do Norte com o nome de Panem".

Disponível em: https:// jogosvorazes.fandom. com/wiki/Panem.

Acesso em: 06 fev. 2021
A partir deste princípio, a representação criou uma infinidade de convenções baseadas na cumplicidade mais ou menos manifesta do locutor da ficção com o interlocutor presente extraficcional. [...] Assim, o texto pode situar as personagens agindo e expressando-se dentro do plano extritamente ficcional, mantendo o espectador como receptor privilegiado do que poderíamos chamar de espetáculo da comunicação. A comunicação é convertida em espetáculo e se oferece a um espectador passivo, nesse caso. Mas isso ainda é relativo, porque aceita que o receptor que está fora da ficção na situação de comunicação não está diretamente envolvido, as estratégias dramáticas que um autor utiliza nessas ocasiões podem dosificar a informação, de maneira que o receptor exterior saiba mais que o receptor da ficção ou, ao contrário, que o receptor interno à ficção saiba mais coisas que o receptor externo. ${ }^{24}$ (ABELLAN, 2000, p. 37-38, grifo nosso e tradução nossa).

Essa característica mantém o leitor em estado de atenção constante, o que é bastante produtivo para a prática leitora da faixa etária à qual é destinada. Para Ball (2008, p. 55, grifo do autor), "em nosso não saber reside a aventura da peça". Esse recurso é utilizado para manter o interesse do espectador, bem como para enfatizar os momentos importantes da composição, marcando as impressões que o autor pretende provocar em seu auditório.

Ainda acerca da ação humana para o desencadeamento ou agravamento da crise ambiental instaurada nos mundos representados, pela própria temática, elas devem retroceder ao passado e a atitudes mais permanentes da sociedade. Assim, o desrespeito aos limites dos recursos naturais do planeta são centrais nos acontecimentos de Wall-E e $A$ vida no céu, enquanto conflitos bélicos acarretam as realidades de Jogos vorazes ${ }^{25}$ e Nausicaä do Vale do Vento. Em Perdidos no espaço, espera-se que a temporada final, a ser disponibilizada em 2021, revele mais sobre o cataclisma terrestre que obrigou os humanos a abandonarem o planeta. Até o momento, sabe-se que um meteoro atingiu a Terra, mas suspeita-se que, de alguma forma, ações humanas tenham levado ao acontecimento.

Nesse sentido, a narrativa distópica evidenciaria um pessimismo em relação à condição e às ações do ser humano atual inserido no mundo concreto. Por ser um futuro possível ou, pelo menos, plausível - de caráter eminentemente negativo, a distopia despertaria no leitor uma consciência dos prejuízos causados pelos nossos atos do presente. 
${ }^{26}$ Dystopia used to be a fiction of resistance; it's become a fiction of submission, the fiction of an untrusting, lonely, and sullen twenty-first century, the fiction of fake news and infowars, the fiction of helplessness and hopelessness. It cannot imagine a better future, and it doesn't ask anyone to bother to make one. (LEPORE, 2017, n. p.).
Por fim, uma narrativa de esperança

Retomando a citação de Berriel (2005, p. 6-7), uma vez que as distopias realçam "tendências negativas operantes no presente", um primeiro olhar sobre elas pode acreditá-las pessimistas. Lepore já manifesta este ponto de vista:

A distopia era uma ficção de resistência, mas se tornou a ficção de submissão, a ficção de um pouco confiável, solitário e sombrio século XXI, a ficção de "fake news" e da guerra da informação, a ficção do desamparo e da desesperança. Ela não pode imaginar um futuro melhor, e não se preocupa em construir um ${ }^{26}$. (LEPORE, 2017, n. p., tradução nossa)

Mas a situação se modifica um pouco quando estamos lidando com distopias voltadas ao público infantojuvenil, nas quais o desfecho tende a colocar toda a narrativa em perspectiva.

Em nosso corpus, podemos observar justamente o contrário do "desamparo e desesperança", porque o otimismo é uma característica marcante da distopia em sua vertente infantojuvenil. Isso evidencia que o discurso, qualquer que seja, é pensado na relação que o autor estabelece com seu leitor, percebendo "o papel ativo tanto de um quanto de outro sem o qual a interação não acontece" (MACHADO, 2017, p. 156). Ao mesmo tempo, também revela a visão que o autor tem de seu auditório. No caso do discurso direcionado ao público infantojuvenil, há uma necessidade contemporânea de não provocar experiências ruins ou que deixem, ao final, uma marca desagradável no mundo deles. Para Zilberman, o final feliz é uma das coerções direcionadas ao público infantojuvenil:

na ausência de um desfecho, e sobretudo do sucesso do protagonista na empresa, o leitor [criança ou adolescente] transferirá a dificuldade para si mesmo, o que repercutirá negativamente nele, enquanto sintoma de impotência e angústia. (ZILBERMAN, 1985, p. 100).

O próprio surgimento do seguimento young adults (os jovens adultos descritos na nota 8) exprime esta visão.

Em Jogos vorazes, a Resistência consegue vencer a Capital e, quando uma nova ditadora (Presidente Coin) parece assumir o controle, Katniss (a protagonista) interrompe sua ascensão e acaba voltando a morar reclusa no Distrito $12 \mathrm{com}$ seu par 
${ }^{27} \mathrm{O}$ mesmo processo pode ser percebido em diversos outros objetos artísticos, como as telenovelas, cuja tópica do conflito "mocinho versus vilão" foi bastante desgastada ao longo das décadas de hegemonia na audiência e atualmente passa por uma reconfiguração.

${ }^{28}$ [The Hunger Games, ] like all Y.A. dystopian fiction, it's also addressed to readers who feel betrayed by a world that looked so much better to them when they were just a bit younger. (LEPORE, 2017 , n. p.). romântico, Peeta. Ou seja, há a perspectiva de um futuro melhor, do qual a protagonista não participa - ou participa de outra maneira, como um anticlímax.

Um pouco mais positivos são os desfechos de $A$ vida no céu e Nausicaä do Vale do Vento. Neste, a jovem princesa do Vale do Vento apresenta uma proposta de nova convivência, mais harmônica, entre os seres humanos e a natureza que os circunda; naquele, Carlos se torna embaixador da Terra Verde e o intermediário entre esta e as comunidades que vivem nos balões e dirigíveis, no céu.

Se a trilogia de Collins apresenta um final apaziguador, mesmo que inesperado, Agualusa e Miyazaki fazem de seus desfechos verdadeiros protestos a favor da preservação ambiental. Nos três objetos, portanto, percebemos projetos ideológicos diferentes, mas todos voltados a adolescentes ou jovens adultos.

A jornalista Raquel Carneiro, em reportagem à Revista Veja quando do lançamento do segundo filme da franquia Jogos vorazes, afirma que há uma descrença dos finais felizes pelo público jovem ${ }^{27}$ :

a novidade, agora, reside no interesse de jovens entre $14 \mathrm{e}$ 23 anos que nunca conviveram com governos totalitários. Público diferente do que presenciou o lançamento de 1984, quando o mundo testemunhava a escalada do comunismo e o temor da aproximação de um futuro ditatorial. (CARNEIRO, 2013 , n. p.).

Já Lepore, que apresenta ponto de vista semelhante quanto à trilogia romanesca, afirma que "[Jogos vorazes,] como todas as ficções distópicas direcionadas a jovens adultos, é também direcionada a leitores que se sentem traídos pelo mundo, que lhes parecia tão melhor quando eram apenas um pouco mais novos." ${ }^{28}$ (LEPORE, 2017, n. p., tradução nossa).

Sendo um objeto artístico direcionado a um mercado editorial massificante, Jogos vorazes responde a interlocutores diferentes daqueles que são respondidos no mangá de Hayao Miyazaki:

O Mar da Podridão era muito mais moral que factual - esta parece ser a lição maior de Nausicaä ao seu povo. O medo foi o salário pago ao homem por não cuidar e não confiar na Natureza. Com seu gesto, Nausicaä dá aos seus próximos 
uma segunda chance de viver em harmonia com a Natureza. O pós-Apocalipse de Miyzaki reverte-se, no fim, de uma nova esperança. Mas não se saber se o que virá será um novo Paraíso, porque não se pode afirmar sem hesitação que o ser humano aprenda com seus erros. (CHAVES; TORRES, 2017, p. 174).

Agualusa, igualmente, termina seu texto com uma mensagem de cautelosa esperança, num final feliz possível, mas ainda não plenamente solidificado:

Na República da Neblina - é assim que os respetivos habitantes chamam à ilha - encontrei, como no céu, pessoas infetadas pela inveja, pelo ciúme, pelo rancor, e por tantas outras doenças que, desde sempre, afligem a humanidade. Contudo, encontrei também corações generosos e uma vontade coletiva de corrigir os erros do passado.

[...]

Conscientes de que não poderão continuar a esconder-se, os cidadãos da República da Neblina requerem a proteção das grandes nações, de forma a preservar o pouco que subsiste das grandes florestas. Aceitam receber grupos restritos de visitantes, na condição de que estes respeitem as leis do território e não perturbem a frágil ecologia da ilha. (AGUALUSA, 2013, p. 111).

Entretanto, de todos os objetos que compõem este corpus, nenhum mais do que Wall-E corresponde tão fielmente ao que diz Zilberman. Sendo uma animação de um grande estúdio hollywoodiano, mercado tradicionalmente direcionado ao público infantil, seu final carrega uma esperança e ludicidade que extrapolam a tensão e os conflitos desenvolvidos ao longo do filme. No fim, a nave Axiom volta à Terra e o filme termina com os humanos desembarcando. Ainda, durante os créditos finais, desenrola-se uma verdadeira utopia da recolonização terrestre. Isso porque o robô EVA apenas conseguiu encontrar um espécime vegetal que floresceu no interior de uma geladeira: todo o restante cenário do planeta é composto literalmente por arranha-céus do lixo que Wall-E recolhe das montanhas de resíduos espalhadas por toda a extensão terrena.

Dessa forma, apesar da gravidade do desastre e da responsabilidade do ser humano, a esperança persiste e o final feliz prevalece nas narrativas infantojuvenis. Contudo, não há como "desver" o já visto, "desler" o já lido, "desimaginar" o imaginado. Se a mensagem final é de esperança, ela não 
suplanta a degradação e a guerra que marcam o presente ou o passado da narrativa. Diretamente relacionado com o descrédito pelos finais felizes das narrativas, portanto, esse sentimento agridoce no desfecho das narrativas distópicas se torna um atrativo para o auditório visado pelo segmento.

\section{O herói}

Muito da ambiguidade de sentimentos relatada no item anterior está relacionada com os protagonistas das distopias. Geralmente, uma narrativa distópica segue uma linha temporal diacrônica, que se inicia num futuro possível ou reconhecível com o do leitor, com a inserção de flashbacks ou outras formas referenciais para explicação de como se chegou àquela constituição de futuro. $\mathrm{O}$ que nos toca agora é que toda a narrativa é entremeada com a presença de um herói reconhecível ética e/ou moralmente pela nossa conformação de sociedade:

no corpo da tradição a que pertencem, certamente [os gêneros discursivos] dirão muito mais sobre os sujeitos que os utilizam e neles se constituem, sobre a sociedade atual e suas formas de enfrentar a vida. (BRAIT; PISTORI, 2012, p. 377).

Por isso, a presença do herói reconhecível pelo público visado pela narrativa acaba materializando uma esperança do leitor e da própria narrativa num "futuro melhor", mesmo que aquele presente (nosso futuro), tenha sido desvirtuado:

Terminada a busca do herói, por meio da penetração da fonte, ou por intermédio da graça de alguma personificação masculina ou feminina, humana ou animal, o aventureiro deve ainda retornar com o seu troféu transmutador da vida. O círculo completo, a norma do monomito, requer que o herói inicie agora o trabalho de trazer os símbolos da sabedoria, o Velocino de Ouro, ou a princesa adormecida, de volta ao reino humano, onde a bênção alcançada pode servir à renovação da comunidade, da nação, do planeta ou dos dez mil mundos. (CAMPBELL, 2007, p. 195).

Assim, de acordo com Brait e Pistori (2012) e tomando por escopo as duas perspectivas antagônicas apresentadas em relação às presenças a) do medo de um futuro terrível e b) da esperança suscitada pela figura do herói/protagonista, entendemos que a distopia ultrapassa uma mera formalização 
de uma sequência narrativa ou temática, uma vez que as interrelações que propõe auxiliam na compreensão da vida e da sociedade, bem como ajudam o leitor a respondê-las. Desta forma, o otimismo não é apenas um sentimento individual do autor (empírico ou criador), mas uma categoria de análise:

Cada gênero é capaz de dominar somente determinados aspectos da realidade, ele possui certos princípios de seleção, determinadas formas de visão e de compreensão dessa realidade, certos graus na extensão de sua apreensão e na profundidade de penetração nela. (MEDVIÉDEV, 2016, p. 196).

Nas narrativas analisadas, os heróis estabelecem pontos de contatos em diferentes níveis da experiência cotidiana do adolescente ou jovem adulto. $\mathrm{O}$ mais evidente deles é, sem dúvida, a questão etária. Katniss Everdeen (Jogos vorazes), os três filhos da família Robinson (Perdidos no espaço), Nausicaä (Nausicä̈ do Vale do Vento) e Carlos Tucano e Aimée (A vida no céu), todos correspondem à faixa etária pré-adolescente e adolescente - sendo, portanto, pertencentes ao grupo definido pelo mercado editorial como young adult. Nesse sentido, Wall-E apresenta uma figura mais complexa como protagonista.

Não é possível uma associação tão direta com o robôrealocador de lixo justamente por ele não ser humano. Entretanto, Wall-E apresenta muitas características humanas em seu comportamento - com as quais há a identificação do espectador. Para tal análise, primeiro devemos lembrar que é um filme que caminha por caminhos cômicos, de uma leitura mais leve da vida. Para compreendermos o cômico presente nesse tipo de personificação, Bergson (1987) afirma que a aproximação da condição humana é fomentadora do riso, mas apenas se aliada a uma insensibilidade (afastamento) perante a condição do objeto do riso: "o cômico exige certa anestesia momentânea do coração para produzir todo o seu efeito" (BERGSON, 1987, p. 13).

Isto posto, Wall-E apresenta traços humanos na sua relação de amizade com a barata com quem divide apartamento; no seu gosto por filmes musicais antigos, especialmente Hello, Dolly! (1969); nos diversos momentos em que manifesta medo, ansiedade, obstinação; e, principalmente, quando se apaixona e cuida de EVA e a acompanha quando ela é levada à nave 
Axiom. O amor inocente e jovial de Wall-E, somado às cenas cômicas que protagoniza enquanto cultiva esse amor, remetem à tradição das histórias de primeiro amor adolescentes.

A vida no céu também lança mão da intriga amorosa entre Carlos e Aimée, embora ela não esteja nunca em primeiro plano, pois o objetivo do protagonista esteve mirado, primeiramente, em encontrar o pai e, depois, em encontrar a Ilha Verde. Da mesma forma, Jogos vorazes também encara como secundária a intriga amorosa entre Katniss, Peeta e Gale, enquanto Perdidos no espaço dá um sentido mais cômico aos flertes de Judy e Penny, as filhas mais velhas da família. Por outro lado, na série, a questão sentimental é tratada de maneira bastante séria no relacionamento entre os pais, John e Maureen Robinson.

O que unifica os protagonistas: Wall-E consegue conduzir a humanidade de volta à Terra após 700 anos no espaço; Nausicaä consegue encerrar a guerra entre Torumekia e Gorot e uma promessa de harmonia entre humanidade e natureza; Carlos não apenas descobre a mítica Ilha Verde, mas zela pela sua preservação; Katniss derruba um governo autoritário, estabelecendo a paz em Panem; e os Robinsons, por enquanto, estão conseguindo sobreviver no espaço, apesar de todos os contratempos vividos desde os primeiros segundos da série mas, como dissemos, o encerramento do enredo se dará apenas na próxima temporada.

Alcançar o impossível, portanto, é o ponto de contato entre eles, mas também é o ponto de contato entre eles e a juventude que os assiste ou lê. Em sua análise, Winkler ressalta a identificação que um jovem do século XXI pode ter em relação à jornada empreendida pelos heróis descrita por Joseph Campbell (2007):

E o que você tem em comum com Harry Potter [saga Harry Potter, de J. K. Rowling], Katniss Everdeen [saga Jogos vorazes, de Suzanne Collins] e Frodo [saga O Senhor dos Anéis, de J. R. R. Tolkien]? Bem, você é humano, exatamente como eles. O mito da jornada do herói existe em todas as culturas humanas e continua sendo atualizado, porque nós, humanos, refletimos sobre o nosso mundo através de histórias simbólicas de nossas próprias vidas. Você deixa sua zona de conforto, tem uma experiência que o transforma, então você se recupera e faz isso novamente. Literalmente, você não esmaga dragões ou combate Voldemort, mas você enfrenta problemas 
${ }^{29}$ Vídeo original disponível em: https:// ed.ted.com/lessons/ what-makes-a-heromatthew-winkler. Acessado em: 21 abr. 2021. Versão traduzida disponível em: https:// www.youtube.com/ watch? $\mathrm{v}=$ Stdko2NI $\mathrm{UNI} \& \mathrm{t}=8 \mathrm{~s}$. Acessado em: 06 fev. 2021.

\footnotetext{
${ }^{30}$ A título de exemplo, veja-se o surgimento da Performance enquanto nova forma artística que mescla elementos das artes plásticas e da cena. Em outro âmbito, também se pode pensar $o$ romance Extremamente alto $\mathcal{E}$ incrivelmente perto (FOER, 2006), cuja forma extrapola a tradicionalmente atribuída ao gênero.

${ }^{31}$ Embora um gênero literário não referenciado neste trabalho, podemos encontrar a distopia já em peças como Os que têm a hora marcada (1952), de Elias Canetti. Também nas formas contemporâneas de teatro, o espetáculo colaborativo Concílio da destruição (2014), da Companhia paulistana Les Commediens Tropicales, a temática distópica figura.
}

assustadores da mesma forma. [...] Qual a caverna simbólica na qual você tem medo de entrar? Testes para uma peça de escola, testes para o baseball, amor? (O QUE faz um herói?..., 2012 $)^{29}$

Sendo o fio condutor do principal auditório esperado pelas obras, o protagonista o conduz pela narrativa de forma sistemática: apresenta-lhe o mundo em crise e como sobrevive nele; demonstra como a presença/existência da humanidade agravou o estado natural do mundo, a ponto de causar a crise; faz prevalecer sua vontade transformadora sobre todas as qualidades negativas do mundo e de sua própria condição humana.

\section{Para além do literário, o discursivo}

Até o momento, temos discutido a distopia como um gênero literário, o que é uma posição acadêmica razoavelmente consolidada. Contudo, buscamos extrapolar a questão meramente literária e entender a distopia - e, por indução, também a utopia - como gênero discursivo de acordo com a teoria proposta pelo Círculo de Bakhtin. Mas, sendo uma narrativa, por que não a subvencionamos ao romance, gênero largamente discutido por Bakhtin?

Certamente concordamos com o estudioso, quando ele diz que, depois do surgimento do romance, ele molda todas as demais formas artístico-discursivas: "Na presença do romance, todos os gêneros começam a soar de modo diferente." (BAKHTIN, 2019, p. 109).

Poderíamos até atribuir ao gênero romanesco as primeiras formas de manifestações artísticas distópicas, todas ligadas ao romance ou, com menor frequência, às narrativas curtas. Mas, na segunda metade do século XX e neste início de século XXI, a arte vem se modificando de maneira vertiginosa, especialmente no que diz respeito à hibridização de formas e gêneros convencionais ${ }^{30}$. Assim, a distopia estabelece trânsitos e cruzamentos endógenos com diversos outros gêneros literários, desde a utopia - derivada da qual primeiramente surge até a ficção científica. Além disso, a distopia, neste período, extrapola o campo literário e se insere na cinematografia, teatro ${ }^{31}$, animação, mangá, animê e outras formas artísticas, como demonstrado pela variedade do nosso corpus. 
${ }^{32}$ Així doncs, donem per acceptat d'entrada que el teatre és també, a part d'altres coses $i$ amb les seves especificitats, un discurs narratiu, cosa que vol dir, tot simplement, que una de les característiques que el defineixen és que explica històries, és a dir, successions d'esdeveniments, i que per tant és una matèria susceptible de ser estudiada, també, des d'aquest punt de vista, per exemple per les teories modernes de la narració. (SALA, 2000, p. 21).

${ }^{33}$ A questão da recomendação da faixa etária dos filmes foi discutida acima.

Acrescentamos, porém, que a questão do interlocutor presumido dos objetos artísticos levantados, especialmente Wall-E e Jogos Vorazes, é mais complexa que isto, como se pode ver em reportagens como a do jornal El País (Brasil), em 17 de agosto de 2015, cujo título é "Sete momentos em que a

Pixar se esqueceu que havia crianças na sala". Um dos sete momentos descreve justamente a relação amorosa entre Wall-E e EVA em Wall-E. Disponível em: https://brasil.elpais. com/brasil/2015/07/ 15/cultura/ 1436959269_596682. html. Acesso em: 20 ago. 2020.
A questão da variedade no que diz respeito à materialidade das obras selecionadas como corpus deste trabalho pode suscitar um primeiro momento de estranhamento. Se deixamos que ele perdurasse até agora, foi com o propósito de fazer o leitor sempre atento a essa especificidade, apesar ou justamente pelo incômodo nele provocado. Faz parte de uma vertente da crítica contemporânea sobre o objeto artístico dividi-lo por sua materialidade. Assim, há os estudiosos de cinema, de literatura, de quadrinhos, de teatro, de artes plásticas, que dominariam a técnica daquela materialidade específica. Entretanto, já diz Bakhtin que

pode-se dizer que a estética material, como hipótese de trabalho, é inócua e, numa conscientização clara e metódica dos limites do seu emprego, pode até tornar-se fecunda, se for estudada apenas a técnica da obra de arte, mas tornar-se-á evidentemente prejudicial e inaceitável quando, baseado nela, se tentar compreender e estudar a obra de arte como um todo, na sua singularidade e significação estéticas. (BAKHTIN, 2014, p. 19, grifo do autor)

Por ser basicamente constituída em narrativa, a distopia encontra espaço em todas as materialidades em que uma história pode ser contada, mas deixa sua marca em todas elas. Tomamos como metonímia a análise realizada por Sala sobre a relação entre teatro e narrativa:

Isto porque concordamos em aceitar de entrada que o teatro é também, à parte outras coisas e com seus expedientes específicos, um discurso narrativo, coisa que quer dizer, simplesmente, que uma das características que o definem é que explica histórias, ou seja, sucessões de eventos, e que, portanto, é uma matéria suscetível de ser estudada, também, deste ponto de vista, por exemplo pelas teorias modernas da narração ${ }^{32}$. (SALA, 2000, p. 21, tradução nossa).

Nosso corpus, portanto, é constituído de objetos artísticos muito diferentes entre si, compostos e veiculados por diferentes meios e direcionados predominantemente ${ }^{33}$ a uma determinada faixa etária, mas que são marcadamente identificados como distopias. Encontramos justificativa e suporte para a unidade dos objetos enquanto gênero no que diz Medviédev:

o gênero é um conjunto de meios de orientação coletiva na realidade, dirigido para seu acabamento. Essa orientação é capaz de compreender novos aspectos da realidade. A 
34 A palavra "veículos" foi usada, aqui, em relação ao contexto da discussão - a análise dialógica do discurso visando a possibilidade da distopia enquanto gênero discursivo - e não interfere na análise de demais gêneros (literários ou discursivos) no mesmo discurso. Já Bakhtin diz que "é muito importante e interessante $o$ problema da interação dos gêneros na unidade da literatura de um dado período.

Em certas épocas [...], todos os gêneros, até certo ponto, complementam uns aos outros de forma harmoniosa, e toda a literatura, enquanto conjunto de gêneros, é consideravelmente um todo orgânico de ordem superior. [...] [Mas] o romance parodia os outros gêneros (precisamente enquanto

gêneros), desvela o convencionalismo de suas formas e de sua linguagem, desloca alguns gêneros, incorpora outros à sua própria construção, reinterpretando-os e reacentuando-os" (BAKHTIN, 2019, p. 67-68). Também Fitting (2010) parte de pressuposto análogo, em sua análise entre os gêneros literários.

\footnotetext{
35 "Esses enunciados [concretos e únicos] refletem as condições específicas e as finalidades de cada referido campo [da atividade humana] não só por seu conteúdo (temático) e pelo estilo da linguagem, ou seja, pela seleção dos recurso lexicais, fraseológicos e gramaticais da língua, mas, acima de tudo, por sua composição composicional."

(BAKHTIN, 2016, p. 11-12).
}

compreensão da realidade desenvolve-se e origina-se no processo de comunicação social ideológica. (MEDVIÉDEV, 2016, p. 200).

Quando não distinguimos mais o objeto artístico-literário fechado em torno apenas de sua materialidade, mas levamos em conta, em sua composição, todo um entorno que lhe altera os significados, renunciamos a moldes pré-fabricados para realizar uma análise calcada na concretude do discurso que se nos apresenta. $\mathrm{Ou}$, nas palavras de Machado:

\begin{abstract}
Graças a essa abertura conceitual é possível considerar as formações discursivas do amplo campo da comunicação mediada, seja aquela processada pelos meios de comunicação de massa ou das modernas mídias digitais, sobre o qual, evidentemente, Bakhtin nada disse, mas para o qual suas formulações convergem. (MACHADO, 2017, p. 152).
\end{abstract}

Essa abertura de que fala Machado no excerto acima nos possibilitou cogitar o trânsito da distopia em diferentes veículos ${ }^{34}$, uma vez que ela é centrada em determinado conteúdo temático, com determinação de traços específicos na abordagem estilística ou na construção composicional ${ }^{35}$. Nesse sentido, Leite, Mello e Martins (2016) equiparam os elementos elencados por Bakhtin no seu "O problema do conteúdo, do material e da forma na criação literária" às noções de tema, composição e estilo, respectivamente, apresentadas como base para elaboração da sua teoria dos gêneros do discurso ${ }^{36}$.

Ainda, o estudioso russo diz que o conteúdo e a forma são, junto à materialidade, elementos constituintes do objeto artístico, no sentido em que "o conteúdo representa o momento constitutivo indispensável do objeto estético, ao qual é correlativa a forma estética que, fora dessa relação, em geral, não tem nenhum significado." (BAKHTIN, 2014, p. 35, grifo do autor). Assim, buscaremos compreender primeiramente os aspectos de forma e conteúdo da distopia, de modo a apreendê-la como discurso artístico inserido no mundo.

Iniciamos, portanto, pelo "momento constitutivo indispensável do objeto estético": o conteúdo. A distopia é, antes e acima de tudo, um conteúdo presente nas obras artísticas, o qual subvenciona a forma em que o material será "moldado": 


\footnotetext{
${ }^{36}$ Fazendo o cotejo, os autores demonstram uma unidade no pensamento de Bakhtin, presente em um texto de sua juventude $(O$ problema do conteúdo, do material e da forma na criação literária, de 1924) e de sua maturidade $(\mathrm{Os}$ gêneros do discurso, de 1953). Optamos por seguir o caminho analítico proposto no texto de 1924 por acreditarmos que os termos então utilizados pelo autor russo dialogam de forma mais direta com o leitor não versado na teoria bakhtiniana.

${ }^{37}$ Para detalhamento desta parte da teoria bakhtiniana, consultar Bajtín (1997).
}

\begin{abstract}
Nós, de pleno acordo com o uso tradicional da palavra, chamamos de conteúdo da obra de arte (mais precisamente, do objeto estético) à realidade do conhecimento e do ato estético, que entra com sua identificação e avaliação no objeto estético e é submetida a uma unificação concreta, intuitiva, a uma individualização, a uma concretização, a um isolamento e a um acabamento, ou seja, a uma formalização multiforme com a ajuda de um material determinado. (BAKHTIN, 2014, p. 35, grifo do autor).
\end{abstract}

Num primeiro momento, Bakhtin relaciona o conteúdo a um valor estético, que se coloca em oposição aos valores éticos e $\operatorname{cognitivos}^{37}$, ou seja, ela não é captada nem plenamente pela racionalidade (cognitivo), nem apenas pelas ações realizadas no mundo (atos éticos). Então, em nosso corpus, não estamos falando especificamente do aquecimento global, do acúmulo de lixo ou das guerras. O que há de conteúdo é o pensamento que projeta os objetos estéticos no mundo: no caso das distopias ambientais, do mal que o homem faz ao meio ambiente - nas distopias em geral, do mal que o homem causa ou pode causar. "A distopia é afinal, espelho da suspensão da História; sua imagem é o exílio da humanidade, tornada resíduo, esta, pela razão enlouquecida." (BERRIEL, 2005, p. 9-10).

Na distopia, ainda recorrendo à citação longa de Bakhtin acima, há duas figuras que atuam em sua configuração de conteúdo: o autor e o auditório - no nosso caso, o espectador ou o leitor. Mas ambas as figuras só são distinguidas a partir da forma:

Assim, a forma é a expressão da relação axiológica ativa do autor-criador e do indivíduo que percebe (co-criador da forma) com o conteúdo; todos os momentos da obra, nos quais podemos sentir a nossa presença, a nossa atividade relacionada axiologicamente com o conteúdo, e que são superados na sua materialidade por essa atividade, devem ser relacionados com a forma. (BAKHTIN, 2014, p. 59).

Existe um discurso comum elaborado entre eles, que nas distopias ambientais é muito claro: "parem (ou paremos, para os autores mais conscientes) de destruir a natureza", como se vê nas diversas análises realizadas sobre os objetos do nosso corpus: 
38 "The film suggests that the kind of hyper-capitalism represented by Buy n Large facilitates a destructive cycle of mass production and consumption, ultimately resulting in environmental apocalypse and the cultural degeneration of the human species". (ANDERSON, 2012, p. 268)
O filme [Wall-E] sugere que o tipo de hiper-capitalismo representado pela Buy $n$ Large intermedeia o ciclo destrutivo da produção de massa e consumismo, finalmente resultando no apocalipse ambiental e na degeneração cultural da espécie humana $^{38}$. (ANDERSON, 2012, p. 268, tradução nossa).

Katniss [em Jogos vorazes] vive no país pós-apocalíptico de Panem, em uma data futura próxima não especificada, que de acordo com a história de fundo do filme, é composto pelos antigos Estados Unidos da América, agora transformados em 13 distritos numerados e uma capital, num cenário onde um cataclisma ambiental inundou as costas leste e oeste do País, estabelecendo um governo totalitário nas planícies centrais da América. Como consequência, os distritos mais atingidos pela destruição ambiental e isolados são subservientes à capital, e produzem cada um, isoladamente, uma produção industrial específica que serve aos propósitos da Capital deste Estado fascista futuro. (CORDEIRO; GOES; NOGUEIRA, 2016, p. 263).

Em A vida no céu: Romance para jovens e outros sonhadores (2015), $o$ dilúvio, causado pelo aquecimento global, ocasionando o desaparecimento dos países terrestres, obriga os seres humanos a buscarem novos meios de sobrevivência, a partir da construção de sociedades flutuantes. No entanto, a condição socioeconômica é decisiva em relação às possibilidades de sobrevivência. (SILVA, 2018, p. 121).

[Em Miyazaki,] o sentimento de admiração pela natureza faz parte de cada uma das características de seus animês onde dá uma mensagem sutil ou explícita: que os seres humanos afetam o meio ambiente e que a ciência e o progresso devem ter cuidado nesta área senão consequências desastrosas esperam por nós. (LUYTEN, 2015, p. 24).

Em todas as análises, é possível perceber a centralidade da temática ambiental vista pelos vieses econômico, geográfico, político, cultural e social - todos eles com um discurso construído com base em um posicionamento, um ponto de vista em relação a cada um desses vieses, outra característica inerente aos enunciados na teoria bakhtiniana:

Nunca poderemos compreender a construção de um enunciado (por mais autônomo e finalizado que ele nos pareça) sem considerar que ele é só um momento, uma gota no fluxo da comunicação discursiva, tão ininterrupto quanto a própria vida social e a própria história. (VOLÓCHINOV, 2019, p. 267). 
A concepção do autor acerca da relação do homem com o mundo deve ser apropriada pelo seu auditório, que vai completá-la com base na sua própria experiência no mundo sensível: "na distopia a realidade não apenas é assumida tal qual é, mas as suas práticas e tendências negativas, desenvolvidas e ampliadas, fornecem o material para a edificação da estrutura de um mundo grotesco" (BERRIEL, 2005, p. 7).

Portanto, a distopia, como qualquer atividade estética,

${ }^{39}$ Não podemos deixar de lembrar do poema "Autopsicografia", de Fernando Pessoa, no qual ele descreve as três dores de um poema: a dor que o autor empírico (pessoa real) sentiu para a escrita do poema, a dor que é descrita no poema e a dor que o leitor sente ao ler o poema. As duas dores sentidas compõem o conteúdo da obra artística; a dor que está no poema é a forma que este conteúdo toma, através da materialidade da palavra escrita. não cria uma realidade inteiramente nova. Diferentemente do conhecimento e do ato, que criam a natureza e a humanidade social, a arte celebra, orna, evoca essa realidade preexistente do conhecimento e do ato - a natureza e a humanidade social - enriquece-as e completa-as, e sobretudo ela cria a unidade concreta e intuitiva desses dois mundos, coloca o homem na natureza, compreendida como seu ambiente estético, humaniza a natureza e naturaliza o homem. (BAKHTIN, 2014, p. 33, grifo do autor).

A forma da distopia, portanto, é o recorte do conteúdo, formalizado para que o seu auditório tenha contato com ele. ${ }^{39}$

Os elementos da distopia apresentados na seção anterior, então, são constituintes da sua forma discursiva, pois extrapolam o meramente material (o filme, o romance, o mangá), mas ainda assim constituem uma unidade. A forma tem este duplo direcionamento, pois olha para dentro e para fora do objeto estético propriamente dito; a forma é material, mas se refere ao conteúdo.

Se assim é, qual a importância do material na constituição do objeto estético? A essa pergunta, Bakhtin responde:

O significado do material na obra de arte é definido da seguinte forma: sem entrar no objeto estético, em sua determinação material extra-estético, como um componente esteticamente significante, ele é indispensável à sua construção como momento técnico. (BAKHTIN, 2014, p. 55).

Contudo, ainda hoje em dia, a materialidade do objeto artístico é tomada como pedra de toque de análises que se pretendem estéticas. Atribuímos esse fenômeno a dois motivos, além dos já levantados por Bakhtin no início do século passado e que reverberam até a atualidade. Um deles é a força com que a tecnologia evoluiu entre o final do século XX e início do XXI, inserindo-se definitivamente nas produções da esfera artística, 
dentro dos mais variados gêneros. Como exemplo, a produção cinematográfica requer de diretores e demais artistas um grande conhecimento técnico das possibilidades tecnológicas para realizar seu trabalho - mas também em artes mais "artesanais", como o teatro e a literatura, a tecnologia interfere em seus modos de produção. Isso demanda tempo, formação, dinheiro e empenho dos artistas para a perfeita execução de sua obra, que esteja inserida no mundo contemporâneo e dialogue nesse mundo com o seu leitor ou espectador.

Decorrente, em parte, do mesmo fenômeno, também o excesso de um olhar mecanicista e tecnicista sobre a vida pode interferir nos valores artísticos que espectadores ou leitores, leigos ou especializados, e os próprios artistas atribuem à sua arte. As ciências humanas e as artes vêm perdendo cada vez mais espaço no cotidiano das pessoas, o que de certa forma anula, inviabiliza, desvaloriza ou até impede a apreensão do mundo por meio de outros registros que não o ético-cognitivo. Como já sabemos, pelas palavras acima aventadas de Bakhtin, que não é por essa via que se constrói a apreciação artística, o público simplesmente fica sem instrumentos interpretativos para poder se relacionar com a visão de mundo (conteúdo) proposto pelo artista.

\section{Conclusão}

Segundo Bruno Vaiano,

Uma distopia, portanto, é uma história com uma lição. Em geral, envolve a denúncia de regimes ditatoriais, tirânicos e autocráticos. Mas, mais do que isso, é uma janela escancarada para as consequências de qualquer tentativa de moldar e dar direção a algo tão plural quanto a civilização. (VAIANO, 2016, n. p.)

À vista disso, uma distopia apresenta uma mundividência que é política e socialmente marcada. As distopias que constituem o corpus levantado para este trabalho estão todas sob o termo guarda-chuva da "cultura de massa". Enquanto tal, elas são regidas por um determinado padrão de gosto que uniformiza as formas artísticas com a veiculação de uma visão de mundo massificada: ao mesmo tempo que não considera os loci específicos de enunciação, as formas artísticas da cultura de massa generalizam sua audiência, remetendo-se a ela apenas 
no que há de mais superficial em sua condição. Ainda assim, percebe-se a presença da imagem geral do leitor infantojuvenil como interlocutor na maior parte dos textos.

Na estrutura formal apresentada para a composição da distopia, depreende-se uma estabilidade no que diz respeito à gradação com que a realidade do mundo distópico é apresentada: primeiro, sabe-se como aquele mundo está; depois, vão-se inserindo flashbacks ou pequenas narrativas paralelas que elucidem o que de fato aconteceu para que o mundo atual passasse àquele estado. Ou seja, há uma apresentação geral da catástrofe no início, que vai sendo reforçada ao longo da narrativa, especialmente com inserções que remetem ao passado. Se, de início, já se adivinha uma relação do homem com a catástrofe ocorrida, com as inserções posteriores, essa participação humana se torna cada vez mais contundente.

A revelação da atuação humana para o desastre que assola as narrativas distópicas, então, constrói um olhar específico sobre o homem - que ele é um mal. Entretanto, pela especificidade infantojuvenil da narrativa, essa visão fica ambígua, pois há a identificação positiva com a figura do protagonista. Assim, pode-se associar o binômio pessimismo/ otimismo despertado no leitor ou no espectador de uma obra distópica à ambiguidade do terror/piedade da catarse aristotélica. Sobre o conceito, Eudoro de Sousa traz uma interpretação que coaduna com nosso argumento:

Com efeito, deve haver uma distância óptima entre o cognoscente e o cognoscível, que condicione o mais perfeito conhecimento do que é, ou deve ser, nas suas proporções naturais.

Esta situação à distância propicia ao conhecimento de uma realidade, de outro modo incognoscível, determina a função catártica, não como ética, fisiológica ou hedonística, mas, sim, como principalmente estética e finalmente gnósica. (SOUSA, 2003, p. 100).

A catarse, portanto, não é tomada por nós como um motivador ou mobilizador da ação (esfera ética), seja na narrativa ou na realidade, mas pertencendo prioritariamente à esfera estética da existência. Não lhe ocorre, portanto, uma intencionalidade de mudar o mundo - ao menos em primeiro plano. Mas, decorrente da contemplação estética - e chegamos à leitura de Sousa acerca do termo -, há a apreensão cognitiva 
${ }^{40}$ los géneros son, en este sentido, el lugar donde se intersectan la historia de la lengua y la historia de la sociedad. [...], que permiten la comunicación humana, a la vez que elaboran representaciones posibles del mundo. (OLMOS, 2006, p. 140). do contexto de produção e leitura daquela narrativa, uma vez que o leitor está inserido no mundo, pois

o gênero, na teoria do dialogismo, está inserido na cultura, em relação a qual se manifesta como 'memória criativa' onde estão depositadas não só as grandes conquistas das civilizações, como também as descobertas significativas sobre os homens e suas ações no tempo e no espaço. (MACHADO, 2017, p. 159).

Ao se fazer compreender racionalmente, pois "as distopias são alertas, não sobre governos ou tecnologias em particular, mas sobre a ideia de que a humanidade pode ser moldada em uma forma ideal" (COMO reconhecer uma distopia..., 2016), o objeto artístico em questão interfere na percepção de mundo do seu espectador, modificando-lhe o pensamento, conferindo-lhe consciência. Na tomada de consciência do leitor ou espectador acerca da narrativa e seu diálogo com o contexto centra-se uma percepção ética da realidade. Ao deixar o campo da alienação em que vivia, o leitor avista o pior cenário para a sua própria realidade, externa à narrativa: "os gêneros são, nesse sentido, o lugar onde se interseccionam a história da língua e a história da sociedade [...], que permitem a comunicação humana, uma vez que elaboram representações possíveis do mundo." ${ }^{\prime 40}$ (OLMOS, 2006, p. 140, tradução nossa).

Do encontro da estrutura formal e de conteúdo da distopia com seu interlocutor infantojuvenil e sua concepção de mundo, acreditamos haver-se criado um gênero discursivo que coloca criadores e receptores em diálogo profundo sobre as condições sociais, fazendo com que o objeto estético reverbere nos âmbitos éticos e cognitivos da sua realidade. A variabilidade do material, antes de ser um impedimento para a concretização da distopia enquanto gênero, foi um catalisador, pois possibilitou o acesso desse auditório ao gênero, até então prioritariamente veiculado nas esferas eruditas da literatura. 


\section{REFERÊNCIAS}

ABELLAN, Joan. El text dramàtic. In: SALA, Jordi (ed.). Deu lliçons sobre teatre: text $i$ representació. Girona: Servei de Publicacions de la Universitat de Girona, 2000, p. 35-43.

ALONSO, Aristides Ledesma. Verossimilhança. In E-DICIONÁRIO de Termos Literários (EDTL). Coordenação de Carlos Ceia. Lisboa: Faculdade de Ciências Sociais e Humanas, 2009. Disponível em: https://edtl.fcsh.unl.pt/encyclopedia/ verossimilhanca/. Acesso em: 16 dez. 2019.

ALVES, Jorge. Narrativa. In: E-DICIONÁRIO de Termos Literários (EDTL). Coordenação de Carlos Ceia. Lisboa: Faculdade de Ciências Sociais e Humanas, 2009. Disponível em: https://edtl.fcsh.unl.pt/encyclopedia/narrativa/. Acesso em: 20 ago. 2020.

ANDERSON, Christopher Todd. Post-Apocalyptic Nostalgia: WALL-E, Garbage, and American Ambivalence toward Manufactured Goods. Lit: Literature Interpretation Theory, [S. l.], v. 23, n. 3, p. 267-282, ago. 2012. Disponível em: https://doi.org /10.1080/10436928.2012.703598. Acesso em: 20 ago. 2020.

ARISTÓTELES. Poética. Tradução de Eudoro de Sousa. 7.ed. Imprensa Nacional/Casa da Moeda, 2003.

BAJTÍN, Mijail M. Hacia una filosofía del acto ético. In: BAJTÍN, Mijail M. Hacia una filosofía del acto ético: De los borradores y otros escritos. Comentários de Iris M. Zavala e Augusto Ponzio. Tradução de Tatiana Bubnova. Rubí: Anthropos, San Juan: Universidad de Puerto Rico, 1997. p. 7-81.

BAKHTIN, Mikhail. O problema do conteúdo, do material e da forma na criação literária. In: BAKHTIN, Mikhail. Questões de literatura e de estética: a teoria do romance. 7. ed. Tradução de Aurora Fornoni Bernardini et al. São Paulo: Hucitec, 2014. p. 13-70.

BAKHTIN, Mikhail. Os gêneros do discurso. In: BAKHTIN, Mikhail. Os gêneros do discurso. Organização, tradução posfácio e notas de Paulo Bezerra. São Paulo: Editora 34, 2016. p. 11-70. 
BAKHTIN, Mikhail. O autor e a personagem na atividade estética. In: BAKHTIN, Mikhail. Estética da criação verbal. Tradução de Paulo Bezerra. 6.ed. São Paulo: Martins Fontes, 2018a. p. 3-194.

BAKHTIN, Mikhail. Teoria do romance II: as formas do tempo e do cronotopo. Tradução de Paulo Bezerra. São Paulo: Editora $34,2018 b$.

BAKHTIN, Mikhail. Teoria do romance III: o romance como gênero literário. Tradução de Paulo Bezerra. São Paulo: Editora 34, 2019.

BALL, David. Para trás e para frente: um guia para leitura de peças teatrais (1983). Tradução de Leila Coury. São Paulo: Perspectiva, 2008.

BERGSON, Henri. O riso: ensaio sobre a significação do cômico (1899). 2. ed. Rio de Janeiro: Guanabara, 1987.

BERRIEL, Carlos Eduardo Ornelas. Ficha técnica, índice e editorial. Revista MORUS - Utopia e Renascimento, Campinas, v. 2, p. 1-17, 2005. Disponível em: http://www.revistamorus. com.br/index.php/morus/article/view/132. Acesso em: 20 ago. 2020.

BRAIT, Beth; PISTORI, Maria Helena Cruz. A produtividade do conceito de gênero em Bakhtin e o Círculo. Alfa - Revista de Linguística, São Paulo, v. 56, n. 2, p. 371-401, 2012. Disponível em: https://periodicos.fclar.unesp.br/alfa/article/view/5531. Acesso em: 20 ago. 2020.

CAMPBELL, Joseph. O herói de mil faces. Tradução de Adail Ubirajara Sobral. São Paulo: Pensamento, 2007.

CARNEIRO, Raquel. O mundo cruel (e rentável) da distopia infantojuvenil. Veja, [s. l.], 10 nov. 2013. Seção Cultura. Disponível em: https://veja.abril.com.br/cultura/o-mundocruel-e-rentavel-da-distopia-infantojuvenil/. Acesso em: 20 ago. 2020

CHAVES, Ravena Amorim; TORRES, José Wanderson Lima. Distopia e animação: o universo fantástico em Nausicaä do 
Vale do Vento, de Hayao Miyazaki. Revista dEsEnrEdoS, ano 9, n. 27, p. 169-175, junho 2017. Disponível em: http://desenredos. dominiotemporario.com/doc/27-Artigo-Nausicaa-RavenaACWandersonLT.pdf. Acesso em: 06 fev. 2021.

CLAEYS, Gregory. The origins of dystopia: Wells, Huxley and Orwell. In: CLAEYS, Gregory (ed.). The Cambridge Companion to Utopian literature. Cambridge: Cambridge University Press, 2010. p. 107-134.

COMITÊ de especialistas [...].; ORGANIZAÇÃO MUNDIAL DA SAÚDE. Problemas de salud de la adolescencia: informe de un Comité de Expertos de la OMS ['se reunió en Ginebra del 3 al 9 de noviembre de 1964]. Ginebra: Organizacion Mundial de la Salud, 1965, 30 p. Disponível em: https://apps.who.int/ iris/handle/10665/38485. Acesso em: dia mês abreviado ano completo. Informe técnico n. 308.

COMO reconhecer uma distopia - Alex Glender. [S. 1.: s. n.], 2016. 1 vídeo (6 min). Publicado pelo canal TED-Ed. Disponível em: https://www.youtube.com/watch?v=6a6kbU88wu0\&t. Acesso em: 20 ago. 2020.

CORDEIRO, Marcus Augusto da Silva; GOES, Beatriz Silva; NOGUEIRA, Wilson de Souza. Jogos Vorazes e a questão da distopia na série de filmes de Gary Ross e Francis Lawrence. Revista GEMInIS, [s. l.], v. 7, n. 1, p. 257-272, jul. 2016. Disponível em: https://www.revistageminis.ufscar.br/index.php/geminis/ article/view/261. Acesso em: 06 fev. 2021.

FITTING, Peter. Utopia, dystopia and science fiction. In: CLAEYS, Gregory (ed.). The Cambridge Companion to Utopian literature. Cambridge: Cambridge University Press, 2010. p. 135-152.

GEISLER, Luisa. Um panorama de nossos medos: o sucesso da ficção distópica no mercado brasileiro mostra o interesse em sobreviver às dificuldades do presente. Quatro cinco um, [S. l.], ano 3, n. 29, p. 42-43, dez. 2019. Disponível em: https:// www.quatrocincoum.com.br/br/resenhas/l/ um-panoramade-nossos-medos. Acesso em: 20 ago. 2020. 
KOPP, Rudinei. Comunicação e mídia na literatura distópica de meados do século 20: Zamiatin, Huxley, Orwell, Vonnegut e Bradbury. 2011. 278 f. Tese (Doutorado em Comunicação Social) - Pontifícia Universidade Católica do Rio Grande do Sul, Porto Alegre, 2011. Disponível em: http://tede2.pucrs.br/ tede2/handle/tede/4473.

LEITE, Francisco de Freitas; MELLO, Patrícia Gomes de; MARTINS, Edson Soares. Pontos de diálogo entre os textos $O$ problema do conteúdo, do material e da forma na criação literária e Os gêneros do discurso, de M. M. Bakhtin: algumas possibilidades de aplicação no ensino de línguas. Signótica, Goiânia, v. 28, n. 2, p. 363-380, jul/dez 2016. Disponível em: https://www.revistas. ufg.br/sig/article/view/34913. Acesso em: 20 ago. 2020. DOI: https://doi.org/10.5216/sig.v28i2.34913.

LEPORE, Jill. A Golden age for dystopian fiction: what to make of our new literature of radical pessimism. The New Yorker, [S. l.], 29 maio 2017. Disponivel em: https://www.newyorker. com/magazine/2017/06/05/a-golden-age-for-dystopian-fiction. Acesso em: 20 ago. 2020.

LIMA, Luiz Costa. Estruturalismo e Teoria da Literatura. Petrópolis: Vozes, 1973.

LUYTEN, Sonia M. Bibe. Glocalização e steampunk nos animês e mangás: a passagem do local para o global no universo da fantasia e a tecnologia a vapor da estética steampunk. $9^{a}$ Arte (São Paulo), [S. l.], v. 4, n. 1, p. 16-25, 2015. Disponível em: http:// www.revistas.usp.br/nonaarte/article/view/136972. Acesso em: 20 ago. 2020.

MACHADO, Irene. Gêneros discursivos. In: BRAIT, Beth (org.). Bakhtin: conceitos-chave. São Paulo: Contexto, 2017. p. 151-166.

MEDVIÉDEV, Pável Nikoláievitch. O método formal nos estudos literários: introdução crítica a uma poética sociológica. Tradução de Ekaterina Vólkova Américo e Sheila Camargo Grillo. São Paulo: Contexto, 2016.

O QUE faz um herói? Matthew Winkler. [S. 1.: s. n.], 2012. 1 vídeo (4 min). Publicado pelo canal TED-Ed. Tradução: 
Isabel Villan. Disponível em: https://www.youtube.com/ watch?v=Hhk4N9A0oCA. Acesso em: 20 ago. 2020.

OLMOS, Candelaria de. Género discursivo. In: ARÁN, Pampa Olga. Nuevo diccionario de la teoría de Mijaíl Bajtín. Córdoba: Ferreyra Editor, 2006. p. 134-141.

PESSOA, Fernando. Autopsicografia. Disponível em: http:// arquivopessoa.net/textos/4234. Acesso em: 20 ago. 2020.

SALA, Jordi. El teatre com a discurs narratiu de ficció. In: SALA, Jordi (ed.). Deu lliçons sobre teatre: text i representació. Girona: Servei de Publicacions de la Universitat de Girona, 2000, p. 21-34.

SANGUINO, Juan. Sete momentos em que a Pixar se esqueceu que havia crianças na sala. El País (Brasil), [s. l.], 17 jul. 2015. Seção Cultura. Disponível em: https://brasil.elpais.com/ brasil/2015/07/15/cultura/1436959269_596682.html. Acesso em: 20 ago. 2020.

SCHOEN-FERREIRA, Teresa Helena; AZNAR-FARIAS, Maria; SILVARES, Edwiges Ferreira de Mattos. Adolescência através dos séculos. Psicologia: Teoria e Pesquisa, Brasília, v. 26, n. 2, p. 227-234, Jun. 2010. Disponível em: http://www.scielo.br/scielo. php?script $=$ sci_arttext\&pid $=S 0102-37722010000200004 \& \ln$ g=en\&nrm=iso. Acesso em: 20 ago. 2020. DOI: https://doi. org/10.1590/S0102-37722010000200004.

SILVA, Elesa Vanessa Kaiser da. Distopia em foco: a perspectiva de vida entre as nuvens em A vida no céu: Romance para jovens e outros sonhadores (2015), de José Eduardo Agualusa. Revista Letras Raras, [S. l.], v. 7, p. 117-129, dez. 2018. Disponível em: http:// revistas.ufcg.edu.br/ch/index.php/RLR/article/view/1173. Acesso em: 20 ago. 2020. DOI: http://dx.doi.org/10.35572/rlr. v7i0.1173.

SOUSA, Eudoro de. A essência da tragédia. In: ARISTÓTELES. Poética. Tradução de Eudoro deSousa. 7.ed. Imprensa Nacional/ Casa da Moeda, 2003. p. 81-100.

TURMA DO FUNDÃO. Seis referências históricas em “Jogos vorazes". Superinteressante, [s. l.], 19 out. 2016. Seção Mundo 
Estranho. Disponível em: https://super.abril.com.br/blog/ turma-do-fundao/6-referencias-historicas-em-jogos-vorazes/. Acesso em: 20 ago. 2020.

VAIANO, Bruno. Como reconhecer uma distopia. Revista Galileu, [s. l.], 28 nov. 2016. Seção Cultura. Disponível em: https://revistagalileu.globo.com/Cultura/noticia/2016/11/ como-reconhecer-uma-distopia.html. Acesso em: 20 ago. 2020.

VIEIRA, Fátima. The concept of utopia. In: CLAEYS, Gregory (ed.). The Cambridge Companion to Utopian literature. Cambridge: Cambridge University Press, 2010, p. 3-27.

VOLÓCHINOV, Valentin. Estilística do discurso literário II: a construção do enunciado (1930). In: A palavra na vida e a palavra na poesia. São Paulo: Editora 34, 2019, p. 266-305.

WORLD WILDLIFE FUND (WWF). Relatório afirma que consumo humano supera capacidade de recuperação do planeta, [s. l.: s. n.], 24 out. 2006. Disponível em: https://www.wwf.org.br/index. cfm?uNewsID=4400. Acesso em: 20 ago. 2020.

ZILBERMAN, Regina. Introduzindo a literatura infantojuvenil. Perspectiva, Florianópolis, v. 1, n. 4, p. 98-102, jan/dez 1985. Disponível em: https://periodicos.ufsc.br/index.php/ perspectiva/article/view/ 10106/9326. Acesso em: 20 ago. 2020. DOI: https://doi.org/10.5007/\%25x.

\section{Corpus}

MIYAZAKI, Hayao. Nausicaä do Vale do Vento [1983]. Vol. 1 a 5. Tradução de Dirce Miyamura. São Paulo: Conrad, 2006-2009.

MIYAZAKI, Hayao. Nausicaë of the Valley of the Wind [1983]. Vol. 6 e 7. Tradução: Math Thorn. San Francisco: VIZ Media, LLC, 2016-2019.

NAUSICAÄ do Vale do Vento. Direção: Hayao Miyazaki. Japão: Studio Ghibli, 1984. 1 DVD (117 min). Título original: Kaze no Tani no Naushika.

WALL-E. Direção: Andrew Stanton. EUA: Walt Disney Studios, 2008. Streaming Netflix (98 min). Título original: Wall-E. 
COLLINS, Suzanne. Jogos vorazes [2008]. Tradução de Alexandre D’Elia. São Paulo: Rocco, 2010.

COLLINS, Suzanne. Em chamas [2009]. Tradução de Alexandre D’Elia. São Paulo: Rocco, 2011.

COLLINS, Suzanne. A esperança [2010]. Tradução de Alexandre D’Elia. São Paulo: Rocco, 2011.

JOGOS vorazes. Direção: Gary Ross. EUA: Color Force; Lionsgate, 2012. Streaming Netflix (145 min). Título original: The hunger games.

JOGOS vorazes: em chamas. Direção: Francis Lawrence. EUA: Color Force; Lionsgate, 2013. Streaming Netflix (146 min). Título original: The hunger games: catching fire.

JOGOS vorazes: a esperança - parte 1. Direção: Francis Lawrence. EUA: Color Force; Lionsgate, 2014. Streaming Netflix (125 min). Título original: The hunger games: Mockingjay - part 1.

JOGOS vorazes: a esperança - o final. Direção: Francis Lawrence. EUA: Color Force; Lionsgate, 2015. Streaming Netflix (137 min). Título original: The hunger games: Mockingjay - part 2.

AGUALUSA, José Eduardo. A vida no céu: romance para jovens e outros sonhadores. [S. l.]: Quetzal, 2015.

PERDIDOS no espaço. Criador: Irwin Allen. Cinematografia: Sam McCurdy. EUA: Legendary Televison et al., 2018-atual. Série em streaming Netflix. 2 temporadas, 20 episódios. Título original: Lost in space.

\section{Outros objetos artísticos indicados}

WELLS, H. G. A máquina do tempo. Inglaterra: [s. n.], 1895. Título original: The Time Machine.

WELLS, H. G. A guerra dos mundos. Inglaterra: [s. n.], 1898. Título original: The War of the Worlds.

HUXLEY, Aldous. Admirável mundo novo. Inglaterra: [s. n.], 1932. Título original: Brave New World. 
ORWELL, George. 1984. Inglaterra: [s. n.], 1949. Título original: Nineteen Eighty-four.

CANETTI, Elias. Os que têm a hora marcada. Suíça: [s. n.], 1952. Título original: Die Befristeten.

HELLO, Dolly! Direção: Gene Kelly. EUA: [s. n.], 1969. 146 min. Título original: Hello, Dolly!

FOER, Jonathan Safran. Extremamente alto E incrivelmente perto. Tradução de Daniel Galera. São Paulo: Rocco, 2006.

CONCÍLIO da destruição - uma peça da Cia. Les Commediens Tropicales. [S. 1.: s. n.], 2014. 1 vídeo (99 min). Publicado pelo canal Bruta Flor Filmes. Disponível em: https://vimeo. com/151913861. Acesso em: 06 fev. 2021.

\section{ABSTRACT \\ Material Variations, Form and Content Maintenances: Dystopias to Children and Young People}

This study aims to legitimize dystopias as a discursive genre that puts creators and auditory in a deep dialogue about the social conditions in which they live. It starts from dystopias as a literary genre projected in contemporary artistic production aimed at children and young people, connecting aesthetic objects produced in different materials, such as cinema, romance and comics. To better compare the different objects, we compiled as corpus dystopia for children and adolescents with an environmental theme. Dystopia, then, is a narrative told with a certain structure and organization of events: at its beginning, there is a description of a catastrophic but possible future; in its course, there are indications of how things went from the reader's present to the future proposed by dystopia, blaming humanity for that; a soothing ending; and, permeating everything, a hero whose identification with the reader is immediate. The formal stability perceived in 
these statements led us to Bakhtinian theory, especially to the text The problem of content, material and form in verbal art (1924). Since Bakhtin does not perceive the aesthetic object closed in its materiality, he values the content as indispensable, which manifests itself in a form that is putted in a materiality. As the dystopian form described above enunciates a content that is uniquely related to the exterior of the utterance, we also discuss the problem of materiality and why it takes the lead in critical analysis of art objects today. We conclude that dystopia, as a discursive genre, makes the aesthetic object reverberate in the ethical and cognitive spheres of its reality.

Keywords: Dystopia. Literary Genres. Discursive Genres. Children and young people literature.

Carlos Gontijo Rosa é Pós-doutorando no Programa de Estudos Pós-Graduados em Linguística Aplicada e Estudos da Linguagem da Pontifícia Universidade Católica de São Paulo. Bolsista Fapesp, supervisionado pela Profa. Dra. Elisabeth Brait (Assinatura Beth Brait). São Paulo, São Paulo, Brasil.

Beth Brait é Professora dos Programas de Estudos Pós-Graduados em Linguística Aplicada e Estudos da Linguagem/LAEL e Literatura e Crítica Literária da Pontifícia Universidade Católica de São Paulo, São Paulo, São Paulo, Brasil. Bolsista de Produtividade em Pesquisa (PQ 1A). 